\title{
PENYUSUNAN UNDANG-UNDANG DI BIDANG INVESTASI: KAJIAN PEMBENTUKAN OMNIBUS LAW DI INDONESIA
}

\author{
Vincent Suriadinata \\ Kabid hukum di Asosiasi Pengusaha Teknologi, Informasi \& Komunikasi Nasional \\ Korespondensi: vincentsuriadinata@gmail.com
}

\begin{abstract}
Abstrak
Indonesia adalah negara dengan potensi ekonomi yang sangat besar namun masih minim investasi. Banyak faktor yang menghambat kemudahan berusaha sehingga mengurangi minat investor untuk berinvestasi di Indonesia. Indonesia perlu menerapkan omnibus law sebagai jawaban atas permasalahan-permasalahan yang menghambat investasi di Indonesia. Omnibus Law secara sederhana dapat dimaknai sebagai satu undang-undang yang bisa mengubah beberapa undang-undang sekaligus. Terdapat tiga keadaan untuk mempraktekkan omnibus law, yakni undang-undang yang akan diubah berkaitan secara langsung, undang-undang yang akan diubah tidak berkaitan secara langsung, dan undangundang yang akan diubah tidak berkaitan tetapi dalam praktek bersinggungan. Penerapan omnibus law di Filipina, Amerika Serikat dan Turki dapat menjadi perbandingan untuk diterapkan omnibus law yang berbudaya hukum Indonesia. Omnibus law sejatinya adalah teknik dalam penyusunan undang-undang yang bertujuan untuk mewujudkan efisiensi dan efektivitas sehingga sangat mungkin diterapkan di Indonesia. Untuk mewujudkannya diperlukan pemahaman tentang omnibus law dan komitmen politik yang kuat dari DPR maupun Pemerintah Indonesia.
\end{abstract}

Kata Kunci: Indonesia; Investasi; Investor; Omnibus Law.

\begin{abstract}
Indonesia is a state with high economic potential. Unfortunately, the investment growth is quite low due to many factors that inhibit the business development. As a result, the investors are reluctant to invest in Indonesia. Omnibus law might be a solution to tackle the problems. The omnibus Law is simply defined as a statute that may amend some statutes at once. There are three conditions of omnibus law implementation, first, the statute that will be amended is related to the other statutes directly, second, the former statute is not related to others directly, third, the former statute is related to others but it affects each other in practices. A comparison of the omnibus law applications in Philippines, the United States, and Turkey may help to seek the possibility of the omnibus law application in Indonesia without leaving its legal culture. It is believed that the omnibus law is possible to be applied in Indonesia, but it needs an adequate understanding about the omnibus law and a strong political commitment of the House of Representatives of the Republic of Indonesia and the Government of the Republic of Indonesia to implement the omnibus law.
\end{abstract}

Keywords: Indonesia; Investment; Investor; Omnibus Law. 


\section{PENDAHULUAN}

Pada saat pelantikan Presiden dan Wakil Presiden periode 2019 - 2024 yang dilangsungkan tanggal 20 Oktober 2019, Presiden Joko Widodo dalam pidatonya menyampaikan bahwa Indonesia saat ini mengalami bonus demografi, dimana jumlah penduduk usia produktif jauh lebih tinggi dibandingkan dengan jumlah penduduk usia tidak produktif. Hal ini menjadi kesempatan besar sekaligus masalah besar. Kesempatan besar itu akan tercipta manakala Indonesia mampu membangun SDM yang unggul. Hal tersebut harus didukung dengan ekosistem politik dan ekosistem ekonomi yang kondusif. Salah satu caranya yakni dengan menyederhanakan dan memangkas segala bentuk kendala regulasi.

Presiden Joko Widodo mengatakan bahwa pemerintah akan mengajak DPR untuk menerbitkan dua undangundang (UU) besar yakni UU Cipta Lapangan Kerja dan UU Pemberdayaan Usaha Makro, Kecil dan Menengah (UMKM). Masing-masing UU tersebut akan menjadi omnibus law yaitu satu UU yang merevisi beberapa UU, bahkan puluhan UU. Penerapan omnibus law di Indonesia seharusnya dimulai dengan mengubah UU bidang investasi terkait dengan kemudahan perizinan usaha supaya saling menyesuaikan dan tidak tumpang tindih. Dengan demikian harmonisasi UU bidang investasi akan menguntungkan para investor, masyarakat dan negara.

Penulis berpendapat, perlunya mengubah UU bidang investasi terkait dengan kemudahan perizinan usaha karena merujuk pada teori jenjang norma hukum (Stufentheorie) dari Hans Kelsen. Menurut Hans Kelsen:

"Norma-norma hukum itu
berjenjang-jenjang dan berlapis-
lapis dalam suatu hierarki (tata
susunan), dalam arti, suatu norma
yang lebih rendah berlaku,
bersumber dan berdasar pada
norma yang lebih tinggi, norma yang
lebih tinggi berlaku, bersumber dan
berdasar pada norma yang lebih
tinggi lagi, demikian seharusnya
sampai pada suatu norma yang
tidak dapat ditelusuri lebih lanjut
dan bersifat hipotetis dan fiktif yaitu
norma dasar (grundnorm)."

Sejalan dengan hal ini, Maria Farida Indrati berpendapat bahwa "norma dasar itu ditetapkan terlebih dahulu oleh masyarakat sebagai norma dasar yang merupakan gantungan bagi norma-norma yang berada di bawahnya, sehingga suatu norma dasar itu dikatakan presupposed."2

Pasal 7 ayat (1) UU No. 12 Tahun 2011 tentang Pembentukan Peraturan Perundang-Undangan sebagaimana telah diubah dengan UU Nomor 15 Tahun 2019 (UU No. 12 Tahun 2011) memuat jenis dan hierarki peraturan perundang-undangan terdiri atas:
a. Undang-Undang Dasar Negara Republik Indonesia Tahun 1945;
b. Ketetapan Majelis Permusyawa- ratan Rakyat;
c. Undang-Undang/Peraturan Undang;
Pemerintah Pengganti Undang-
d. Peraturan Pemerintah;
e. Peraturan Presiden;
f. Peraturan Daerah Provinsi; dan
g. Peraturan Daerah Kabupaten/ Kota. 
Kekuatan hukum Peraturan Perundang-undangan sesuai dengan hierarki pada Pasal 7 ayat (1) UU No. 12 Tahun 2011.3 Kekuatan hukum Peraturan Perundang-undangan ini erat kaitannya teori jenjang norma hukum Hans Kelsen karena norma yang lebih rendah bersumber dan berdasar dari norma yang lebih tinggi. Sehingga seharusnya peraturan perundang-undangan yang lebih rendah harmonis dengan peraturan perundang-undangan yang lebih tinggi hierarkinya.

Omnibus law atau sering disebut juga omnibus bill adalah:

"1. A single bill containing various distinct matters, usu. drafted in this way to force the executive either to accept all the unrelated minor provisions or to veto the major provisions. 2. A bill that deals with all proposals relating to a particular subject, such as an 'omnibus judgeship bill' covering all proposals for new judgeships or an 'omnibus crime bill' dealing with different subjects such as new crimes and grams to states for crime control."4

Pendapat serupa juga dinyatakan, bahwa omnibus law atau omnibus bill:

"Just like a standard bill, omnibus bills are formal proposals to change laws that are voted on by rank and file lawmakers and sent off to the executive branch for final approval. The difference with omnibus bills is they contain numerous smaller bills, ostensibly on the same broad topic. Take the omnibus tax bill as an example: It may include changes on everything from income, corporate, and sales taxes, but all of those issues can fit under the large umbrella of taxes. ${ }^{5}$

Secara sederhana dapat diterjemahkan bahwa omnibus law atau omnibus bill adalah satu UU yang bisa mengubah banyak UU. Jimly Asshiddiqie dalam mata kuliah perbandingan konstitusi pada tanggal 28 September 2017 menyampaikan tiga keadaan untuk mempraktekkan omnibus law, yakni UU yang akan diubah berkaitan secara langsung, UU yang akan diubah tidak berkaitan secara langsung, dan UU yang akan diubah tidak berkaitan tetapi dalam praktek bersinggungan.

Di Indonesia, omnibus law sempat digagas oleh Sofyan Djalil yang pada saat itu menjabat sebagai Menteri Koordinator Bidang Perekonomian Republik Indonesia. Hal ini melihat kondisi kemudahan berusaha di Indonesia yang dinilai masih sulit dan berbelit-belit. Panjangnya rantai birokrasi, peraturan yang tumpang tindih lintas kementerian, ${ }^{6}$ dan banyaknya regulasi yang tidak harmonis ${ }^{7}$ adalah faktor yang menghambat kemudahan berusaha di Indonesia.

Belum lama ini pemerintah menerbitkan Peraturan Pemerintah

\section{UU No. 12 Tahun 2011}

Bryan A. Garner, ed., Black's Law Dictionary (West Publishing Co 2004) 175.

Briana Bierscbach, 'Everything You Need to Know About Omnibus Bills, and Why They're So Popular at The Minnesota Legislature' (Minnpost, 31 Maret 2017) <https://www.minnpost.com/ politics-policy / 2017/03/everything-you-need-know-about-omnibus-bills-and-why-theyre-so-pop ular-minne> diakses 17 Maret 2018.

6 Anonim, 'Rantai Birokrasi Masih Jadi Kendala Investor Berinvestasi di Indonesia' (Okefinance, 12 Februari 2018) <https://economy.okezone.com/read/2018/02/12/320/1858267/rantai-birokra si-masih-jadi-kendala-investor-berinvestasi-di-indonesia> diakses 27 November 2018.

$7 \quad$ Yayu Agustini Rahayu, 'Regulasi Masih Menjadi Kendala Investasi di Indonesia' (Merdeka.com, 25 September 2018) <https://www.merdeka.com/uang/regulasi-masih-jadi-kendala-investasi-diindonesia.html> diakses 27 November 2018. 
(PP) No. 24 Tahun 2018 tentang Pelayanan Perizinan Berusaha Terintegrasi Secara Elektronik atau yang lebih dikenal dengan Online Single Submission (OSS) untuk mempermudah pemrosesan izin berusaha di Indonesia, namun hal ini saja tidak cukup. Menteri Koordinator Bidang Perekonomian Republik Indonesia, Darmin Nasution menyatakan "setidaknya terdapat 10 sampai $11 \mathrm{UU}$ yang mengatur tentang perizinan berusaha dan diduga mempersulit para investor. Akan dibuat omnibus law untuk mengamandemen 10 sampai 11 UU itu."8

Indonesia bisa belajar dari Filipina yang sudah pernah menerapkan omnibus law di bidang investasi dengan menerbitkan omnibus investment code of 1987. Melalui omnibus investment code of 1987, investor akan diberi sejumlah insentif dan hak-hak dasar yang menjamin usaha mereka di Filipina. ${ }^{9}$ Melihat bentuknya, omnibus investment code of 1987 semacam kodifikasi di bidang investasi, sehingga segala hal terkait pengaturan investasi merujuk pada omnibus investment code of 1987.

Indonesia juga bisa melihat implementasi omnibus law di Amerika Serikat. Contohnya adalah The Omnibus Public Land Management Act of 2009, dimana UU ini menetapkan jutaan hektar lahan di Amerika Serikat sebagai kawasan lindung dan menetapkan sistem konservasi lanskap nasional.10 Pembentukan UU ini diawali karena adanya keprihatinan terhadap perubahan iklim yang dapat mempengaruhi akses terhadap sumber daya air. Selain itu, UU ini juga memiliki muatan recovery act yang diharapkan dapat menghasilkan investasi yang bermanfaat bagi perlindungan dan pemulihan ekosistem di Amerika Serikat. ${ }^{11}$ Mencermati The Omnibus Public Land Management Act of 2009, maka bentuknya adalah UU yang muatannya lebih dari satu materi substantif yang sebelumnya terpisahkan dalam beberapa act/ UU.

Contoh lain penerapan omnibus law terdapat di Turki atau lebih populer disebut torba kanun. Ada hal yang menarik dari torba kanun ini karena dalam pembentukannya terdapat motif politik yakni pemerintah yang notabene oleh partai tunggal mengendalikan pengaturan agenda legislatif. Pemerintah secara sah mengusulkan Rancangan UndangUndang (RUU) yang paling mungkin disetujui oleh parlemen yang notabene didominasi oleh partai yang memerintah. Namun, secara ilegal pemerintah mencegah oposisi atau masyarakat yang meneliti RUU dengan cara menambahkan ketentuan baru dalam RUU setelah dibacakan dalam rapat pleno. Tetapi tujuan dari omnibus law

8 Erric Permana, 'Banyak UU Hambat Usaha, Pemerintah Akan Buat Omnibus Law' (Breaking, 28 Maret 2018) <https://www.aa.com.tr/id/ekonomi/banyak-uu-hambat-usaha-pemerintah-akanbuat-omnibus-law/1101481> diakses 27 November 2018.

9 Regulus E. Cabote, 'Philippines: Investment Incentives Under The Omnibus Investment Code of The Philippines' (Mondaq, 17 Januari 2001) <http://www.mondaq.com/x/9714/Investmen $\mathrm{t}+$ Strategy/Investment+Incentives+Under+The+Omnibus+Investment+Code+Of+The+Philippines $>$ diakses 27 November 2018.

10 Ima Mayasari, 'Menggagas Omnibus Law' (Kumparan, 12 November 2018) <https://kumparan. com/dr-ima-mayasari-m-h/menggagas-omnibus-law-1542018891459839175> diakses 27 November 2018.

11 Barrack Obama, 'Obama Signs The Omnibus Public Lands Management Act of 2009' (New York Times, 30 Maret 2009) <https://www.nytimes.com/2009/03/30/us/politics/30lands-text.html> diakses 27 November 2018. 
di Turki sama dengan penerapan omnibus law di negara lain yakni untuk efisiensi waktu dalam pembahasan dan pengesahan UU. ${ }^{12}$

Omnibus law lazim ditemui di negara dengan sistem presidensil, khususnya Amerika Serikat. Di dalam Kongres Amerika Serikat, omnibus law membantu membentuk konsensus legislatif karena setiap legislator dapat melampirkan RUU nya ke dalam omnibus law. Berbeda halnya dengan di Turki yang pada umumnya pemerintah menolak proposal oposisi di dalam omnibus law nya. Kompleksitas konten yang terkandung dalam omnibus law membuat perhatian oposisi terbelah dalam memberikan kritik dan penentangan karena terlalu banyak masalah yang diperdebatkan dalam waktu yang terbatas. Kesamaan omnibus law di Turki dengan omnibus law pada umumnya hanya karena RUU disahkan dengan cepat dan hampir tanpa kegagalan. ${ }^{13}$

Menurut Maria Farida Indrati "perubahan suatu peraturan perundang-undangan dilakukan, apabila terdapat ketentuan-ketentuan dalam peraturan perundang-undangan tersebut yang tidak sesuai lagi dengan situasi atau kondisi yang berlaku dalam masyarakat."14 Perubahan suatu peraturan perundang-undangan dapat meliputi hal-hal sebagai berikut:

1. Menambah atau menyisipkan ketentuan baru, menyempurnakan atau menghapus ketentuan yang sudah ada, baik yang berbentuk bab, bagian, paragraf, pasal, ayat, maupun perkataan, angka, huruf, tanda baca dan lain-lainnya.

2. Mengganti suatu ketentuan dengan ketentuan lain, baik yang berbentuk bab, bagian, paragraf, pasal, ayat, maupun perkataan, angka, huruf, tanda baca dan lain-lainnya. ${ }^{15}$

Melihat fakta disharmoni UU bidang investasi dan tingkat kemudahan berusaha di Indonesia yang sulit, menjadikan omnibus law dapat diterapkan di Indonesia. Tulisan yang merupakan hasil penelitian ini mendeskripsikan beberapa hal. Pertama, perbandingan penerapan omnibus law di beberapa negara. Kedua, karakterikstik omnibus law. Ketiga, proyeksi dan tantangan penerapan omnibus law di Indonesia.

Tujuan dari penelitian ini adalah untuk membangun suatu argumen bahwa penyusunan UU di bidang investasi dapat menerapkan omnibus law. Atas dasar argumen utama tersebut maka Penulis selanjutnya akan menjabarkannya menjadi argumen yang lebih spesifik sebagai tujuan penelitian yaitu mengargumentasi dan mengidentifikasi karakteristik omnibus law di negara lain dan mengargumentasi bahwa penyusunan UU bidang investasi di Indonesia dapat menerapkan omnibus law.

Dalam penelitian ini digunakan beberapa teori untuk menunjang penulisan. Pertama, teori sistem hukum (legal system) dari Lawrence M.

12 Yasushi Hasama dan Seref Iba, 'Legislative Agenda Setting by A Delegative Democracy: Omnibus Bills in Turkish Parliamentary System' (2017) 18 (2) Turkish Studies 316, 317.

Ibid., 320.

Maria Farida Indrati, Imu Perundang-Undangan I1 (Kanisius 2007) 179.

Ibid. 
Friedman ${ }^{16}$ yang terdiri dari: struktur hukum (legal structure), substansi hukum (legal substance), dan budaya hukum (legal culture). Kedua, teori perundang-undangan menurut A. Hamid S. Attamimi. Ia membedakan antara teori perundang-undangan dan ilmu perundang-undangan.

Menurut A. Hamid S. Attamimi:

"Teori perundang-undangan berorientasi pada menjelaskan dan menjernihkan pemahaman dan bersifat kognitif, sedangkan ilmu perundang-undangan (dalam arti sempit) berorientasi pada melakukan perbuatan pelaksanaan dan bersifat normatif. Teori perundangundangan dan ilmu perundangundangan merupakan cabang atau bagian dari ilmu pengetahuan perundang-undangan."17

Ketiga, teori penyusunan RUU dalam perubahan masyarakat yang demokratis. Penting untuk diketahui dan dipahami oleh para perancang UU bahwa proses penyusunan RUU merupakan bagian yang tidak terpisahkan dari sistem pembuatan UU. Kemampuan untuk membuat konsep terjemahan dari suatu kebijakan menjadi RUU yang dapat dilaksanakan secara efektif diperlukan untuk menghasilkan dampak sosial yang diinginkan.

Untuk menyusun suatu RUU diperlukan kajian yang didukung dengan teori bahwa RUU ini dibuat tidak asal-asalan. Kajian ini yang akan menjadi pertimbangan persuasif terhadap suatu RUU. Menurut Ann Seidman dan kawan-kawan, terdapat empat langkah pemecahan masalah sebagai metodologi untuk menunjukkan bahwa RUU yang diusulkan bertumpu kepada dasar pemikiran berdasarkan pengalaman. Keempat langkah tersebut yakni "identifying the difficulty, proposing and warranting explanations, proposing a solution, dan monitoring and evaluating implementation."18

Untuk mengubah perilaku permasalahan sosial, suatu UU harus ditujukan untuk mengubah atau menghilangkan setiap sebab-sebab perilaku tersebut yang saling terkait. Maka dalam merancang UU, seorang perancang harus memeriksa semua kategori ROCCIPI ${ }^{19}$ untuk mendapatkan masukan tentang proposisi penjelasan yang dapat diuji dan saling berkaitan. Secara sederhana dapat dimaknai bahwa ROCCIPI adalah suatu model untuk mengidentifikasi faktor-faktor yang sering menimbulkan masalah berkaitan dengan berlakunya suatu hukum. ROCCIPI merupakan akronim dari Rule (peraturan), Opportunity (kesempatan), Cappacity (kemampuan), Communication (komunikasi), Interest or Incentives (kepentingan), Process (proses), dan Ideology (ideologi). Ketujuh faktor ini dibagi ke dalam dua kategori faktor penyebab yakni faktor subyektif yang terdiri dari Interest or Incentives dan Ideology (values and attitudes) dan faktor obyektif yang

16 Sescio Jimec Nainggolan, dkk., 'Analisis Yuridis Penentuan Kedudukan Saksi Pelaku Sebagai Justice Colaborators dalam Tindak Pidana Narkotika di Pengadilan Negeri Pematang Siantar' (2017) 5 (3) USU Law Journal 108, 109.

17 H. Rosjidi Ranggawidjaja, Pengantar Ilmu Perundang-Undangan Indonesia (Mandar Maju 1998) 14-15.

18 Ann Seidman, Robert B. Seidman dan Nalin Abeyesekere, Legislative Drafting for Democratic Social Change (Kluwer Law International Ltd 2001) 90-92.

19 Rachmat Trijono, 'Alternatif Model Analisis Peraturan Perundang-Undangan' (2012) 1 (3) Rechtsvinding 361, 362. 
terdiri dari Rule, Opportunity, Capacity, Communication dan Process.

Penelitian ini adalah penelitian hukum normatif. Menurut Soerjono Soekanto dan Sri Mamudji, penelitian hukum normatif atau disebut juga penelitian hukum kepustakaan 20 adalah "penelitian hukum yang dilakukan dengan cara meneliti bahan pustaka atau data sekunder belaka". ${ }^{21}$ Pendekatan yang digunakan penulis dalam melakukan penelitian hukum ini adalah pende-katan perundangundangan (statue approach) dan pendekatan perban-dingan (comparative approach).

Cara pengumpulan bahan hukum atau teknik pengumpulan bahan hukum yang digunakan penulis dalam penelitian hukum ini adalah "studi kepustakaan atau library research."22 Teknik studi kepustakaan (library research), digunakan untuk mendapatkan data sekunder yang diperoleh antara lain melalui: "Bahan hukum primer, yaitu bahan hukum yang bersifat autoritatif, artinya mempunyai otoritas."23 Adapun bahan hukum primer yang digunakan yakni peraturan perundang-undangan. Alasan digunakannya bahan hukum primer karena ditujukan untuk mencari landasan hukum; bahan hukum sekunder, adalah bahan hukum memberikan penjelasan mengenai bahan hukum primer. Alasan digunakannya bahan hukum sekunder adalah untuk mencari landasan teori dengan cara membandingkan satu teori dengan teori lainnya; dan bahan hukum tersier. Alasan digunakannya bahan hukum tersier adalah untuk mencari suatu istilah. Metode analisis data yang digunakan adalah analisis kualitatif. ${ }^{24}$

\section{PEMBAHASAN}

\section{Perbandingan Omnibus Law di 3 Negara}

Perbandingan penerapan omnibus law di beberapa negara yakni Filipina, Amerika Serikat dan Turki menunjukkan ada beberapa persamaan, perbedaan, dan kondisi penerapan omnibus law. Persamaannya adalah banyaknya atau kompleksitas masalah yang diatur menjadikan omnibus law sebagai pilihan untuk mengakomodir kebutuhan tersebut. Jika menggunakan UU konvensional, maka akan membutuhkan waktu yang lama. Artinya antara ketiga negara ini terdapat efisiensi waktu dalam pembahasan dan pengesahan UU.

Perbedaannya adalah ada tidaknya motif politik dalam pembentukan omnibus law. Dalam analisis Penulis, motif politik dalam pembentukan omnibus law hanya ditemukan di Amerika Serikat dan Turki. Sehingga selain hal teknis, terdapat motif politik untuk membentuk sebuah konsensus antara pemerintah dengan parlemen maupun di dalam parlemen itu sendiri. Namun tak jarang motif politik ini menjadi "alat" untuk melangkahi beberapa proses legislasi yang seharusnya ditempuh. Kemudian dilihat dari

20 Depri Liber Sonata, 'Metode Penelitian Hukum Normatif dan Empiris: Karakteristik Khas Dari Metode Meneliti Hukum' (2014) 8 (1) Fiat Justitia 15, 30.

21 Soerjono Soekanto dan Sri Mamudji, Penelitian Hukum Normatif Suatu Tinjauan Singkat (RajaGrafindo Persada 2010) 13-14.

Peter Mahmud Marzuki, Pengantar Penelitian Hukum (Kencana 2014) 438.

Peter Mahmud Marzuki, Penelitian Hukum (Kencana 2005) 181.

Sulistyowati Irianto, 'Metode Penelitian Kualitatif dalam Metodologi Penelitian Ilmu Hukum' (2002) 32 (2) Jurnal Hukum dan Pembangunan 155, 166. 
bentuknya, omnibus law di Filipina umumnya berbentuk kodifikasi; di Amerika Serikat ada yang berbentuk kodifikasi, ada yang tidak; sedangkan di Turki sejauh penelitian Penulis omnibus law nya tidak berbentuk kodifikasi. Omnibus law di Turki lebih banyak mengamandemen ketentuanketentuan yang tersebar di beberapa UU.

Dalam Rencana Pembangunan Jangka Menengah Nasional (RPJMN) Tahun 2004-2009, terdapat permasalahan yang dihadapi dalam peningkatan investasi yakni iklim investasi yang memburuk karena faktor prosedur perijinan investasi yang panjang dan mahal, rendahnya kepastian hukum, lemahnya insentif investasi, kualitas SDM rendah dan terbatasnya infrastruktur, tidak ada kebijakan yang jelas untuk mendorong pengalihan teknologi dari Penanaman Modal Asing (PMA). Hal ini terus menjadi concern dan perhatian hingga tahun 2019 ini.

Menyikapi fakta disharmoni UU bidang investasi dan tingkat kemudahan berusaha di Indonesia yang sulit, pemerintah telah melakukan berbagai upaya untuk mengatasinya. Salah satunya dengan menerbitkan PP No. 24 Tahun 2018 tentang Pelayanan Perizinan Berusaha Terintegrasi Secara Elektronik atau lebih populer disebut PP OSS (Online Single Submission). Platform OSS ini untuk menyederhanakan pengurusan perizinan investasi menjadi satu pintu.
Selain itu, pengajuan izin dijanjikan akan lebih cepat, bahkan hanya dalam satu jam. Dibangunnya sistem OSS karena banyaknya keluhan para investor terkait perijinan dan birokrasi yang berbelit-belit. Penanganannya tidak bisa dipantau sampai sejauh mana berjalan. Dengan aplikasi ini, dipastikan investor bisa memantau langsung perkembangan izin yang diajukan. Jadi begitu ketahuan ijinnya berhenti di pemerintah daerah, misalnya, maka bisa langsung diatasi dengan cepat oleh satuan tugas. ${ }^{25}$ Menurut Presiden Jokowi, dalam waktu yang singkat itu izin-izin permulaan bisa langsung jadi. Izin permulaan itu yakni untuk mendapatkan Nomor Induk Berusaha (NIB). Setelah izin awal dikantongi, maka para investor bisa langsung memulai investasinya sambil menunggu perizinan lain selesai yang disebut service level agreement selama satu bulan menyangkut izin lokasi, izin lingkungan, dan izin mendirikan bangunan. ${ }^{26}$

OSS banyak memberikan dampak positif terhadap iklim investasi di Indonesia karena selain mudah dan cepat, juga tidak dipungut biaya apapun. Sehingga tidak ada lagi yang ditemukan menggunakan jasa calo. ${ }^{27}$ Anggota Komisi VI Dewan Perwakilan Rakyat Republik Indonesia, Juliari Batubara juga mengatakan bahwa sistem OSS juga bisa mengurangi penyelewengan-penyelewengan yang dapat terjadi dalam mengurus

25 Ambaranie Nadia, 'Urus Izin Investasi Hanya 1 Jam dengan Online Single Submission' (Kompas.com, 25 Mei 2018) <https://ekonomi.kompas.com/read/2018/05/25/124931526/ urus-izin-investasi-hanya-1-jam-dengan-online-single-submission> diakses 1 April 2019.

26 Ihsanuddin, 'Tinjau Kantor BKPM, Jokowi Sebut Urus Izin Investasi Hanya Butuh 2 Jam' (Kompas.com, 14 Januari 2019) <https://nasional.kompas.com/read/2019/01/14/12570161/ tinjau-kantor-bkpm-jokowi-sebut-urus-izin-investasi-hanya-butuh-2-jam> diakses 1 April 2019.

27 Muhammad Ikhsan, 'Wabup Dalmasri: Perizinan Online Hindari Pelaku UKM di Bintan dari Calo' (Batamnews.co.id, 27 Maret 2019) <https://www.batamnews.co.id/berita-46208-wabupdalmasri-perizinan-online-hindari-pelaku-ukm-di-bintan-dari-calo.html> diakses 1 April 2019. 
persyaratan perizinan oleh pelaku dunia usaha. Namun bukan berarti OSS tidak mengalami kendala. Masih diperlukan pembenahan dan sinkronisasi antara OSS dengan peraturanperaturan di daerah seperti izin lokasi yang dikeluarkan via OSS. Hal itu lantaran adanya yang tidak sesuai dengan Rencana Detail Tata Ruang (RDTR) di daerah maupun tempat perusahaan pemohon izin berusaha tersebut. Juga adanya pengusaha yang harus melakukan perizinan dari awal karena melakukan pengurusan perizinan sebelum adanya sistem OSS itu. 28

Pemerintah juga telah berupaya untuk memberikan kepastian hukum dengan menerbitkan UU No. 25 Tahun 2007 tentang Penanaman Modal (UU Penanaman Modal), namun hal itu saja tidak cukup. Perlu adanya revisi regulasi dalam rangka penyederhanaan perijinan terkait investasi baik lama proses perijinan maupun jenis perijinan yang diterbitkan oleh kementerian/lembaga; penyusunan regulasi terkait penetapan standar prosedur dan waktu pengurusan perijinan investasi yang akan menjadi payung hukum bagi semua kementerian terkait dan pemerintah daerah untuk mengoptimalkan implementasi pelayanan terpadu satu pintu (PTSP); serta pembenahan regulasi yang mengatur tentang pemberian insentif fiskal dan non fiskal, terutama bagi: (i) investor yang berpartisipasi dalam pembangunan infrastruktur energi nasional; (ii) investor yang mengembangkan industri yang dapat menghasilkan bahan baku atau barang modal sederhana; (iii) investor dalam negeri yang mengembangkan industri pengolahan bahan tambang dalam negeri; serta (iv) investasi sektor minyak dan gas, dengan mempertimbangkan aspek kesulitan geologi dan mendorong peningkatan produktivitas sumursumur tua, eksplorasi daerah baru, dan laut dalam. ${ }^{29}$

Pentingnya menciptakan iklim investasi yang kondusif dan memberikan fasilitas yang menunjang akan meningkatkan investasi di Indonesia. Instrumen untuk menciptakan iklim yang kondusif tersebut adalah hukum. Diperlukan hukum (dalam hal ini undang-undang/peraturan) yang dapat mengakomodir keinginan para investor namun tidak mengabaikan kepentingan nasional. Pemerintah telah berusaha dengan menerbitkan berbagai PP, Peraturan Presiden (Perpres) maupun Peraturan Menteri (Permen) untuk mengakselerasi pertumbuhan investasi di Indonesia. Namun hal itu saja tidak cukup, perlu adanya suatu pengaturan yang terintegrasi sehingga memberikan kepastian hukum dan menghindari adanya disharmoni pera-turan di kemudian hari.

Penulis berpendapat, Indonesia dapat mengadopsi omnibus law untuk menciptakan instrumen hukum investasi yang dapat meningkatkan minat investasi di Indonesia. Hal ini dikarenakan masalah yang diatur dalam hukum investasi sangatlah kompleks. Tidak hanya persoalan

\footnotetext{
28 Wandi, 'DPR Puji Sistem Perizinan Investasi OSS Dunia Usaha' (InfoPublik, 19 Februari 2019) <http://infopublik.id/kategori/politik-hukum/328424/dpr-puji-sistem-perizinan-investasi-ossdunia-usaha?video=> diakses 1 April 2019.

29 Kementerian Perencanaan Pembangunan Nasiona/Badan Perencanaan Pembangunan Nasional, Lampiran Peraturan Presiden Nomor 2 Tahun 2015 tentang RPJMN 2015-2019 Buku II, 3-139140.
} 
investor datang dan menanamkan modalnya, namun terkait erat dengan berbagai aspek seperti ketenagakerjaan, infrastruktur, insentif fiskal maupun non-fiskal dan lain sebagainya. Kompleksitas permasalahan ini lah yang belum diatur di UU Penanaman Modal. Belakangan baru terpikirkan dan diterbitkan pengaturannya dalam bentuk PP, Perpres atau Permen.

Penerapan omnibus law di Filipina terdapat dalam omnibus investment code of 1987 dinyatakan bahwa para pelaku usaha diberikan insentif fiskal maupun non-fiskal jika berinvestasi pada bidang-bidang yang telah ditentukan oleh pemerintah dalam Investment Priorities Plan (IPP). Bentuk-bentuk insentif itu antara lain income tax holiday, additional deduction for labor expense, tax and duty exemption on imported capital equipment, tax credit on domestic capital equipment, dan lain-lain. ${ }^{30}$

Meskipun di Filipina menganut sistem common law, tetapi terdapat kodifikasi yang lazimnya dianut negara-negara sistem civil law seperti omnibus investment code of 1987 yang berupa kodifikasi. Hal ini tidak lepas dari sejarah bahwa Filipina pernah dijajah oleh Spanyol sebelum akhirnya dijajah oleh Amerika Serikat. Selama masa penjajahan Amerika Serikat, kodifikasi tetap dipertahankan meskipun Amerika Serikat menganut sistem common law.
Melihat contoh di atas, dapat diidentifikasi bahwa karakteristik utama penerapan omnibus law di Filipina adalah dibuat dalam bentuk kodifikasi. Kodifikasi hukum menurut R. Soeroso adalah "pembukuan hukum dalam suatu himpunan UU dalam materi yang sama. Tujuannya adalah agar didapat suatu rechtseenheid (kesatuan hukum) dan suatu rechts-zakerheid (kepastian hukum)."31 Sedangkan menurut Satjipto Rahardjo, tujuan umum dari kodifikasi adalah "untuk membuat kumpulan peraturan perundangundangan itu menjadi sederhana dan mudah dikuasai, tersusun secara logis, serasi, dan pasti." 32

Penerapan omnibus law di Amerika Serikat, salah satunya dapat dilihat melalui dokumen The Omnibus Public Land Management Act of 2009, dimana UU ini menetapkan jutaan hektar lahan di Amerika Serikat sebagai kawasan lindung dan menetapkan sistem konservasi lanskap nasional. ${ }^{33}$ Pembentukan UU ini diawali karena adanya keprihatinan terhadap perubahan iklim yang dapat mempengaruhi akses terhadap sumber daya air. Selain itu, UU ini juga memiliki muatan recovery act yang diharapkan dapat menghasilkan investasi yang bermanfaat bagi perlindungan dan pemulihan ekosistem di Amerika Serikat. 34

Menurut Krutz, terdapat dua pendekatan yang menjelaskan kemunculan omnibus law yang berdampak

\footnotetext{
Article 19 Executive Order No. 226, The Omnibus Investments Code of 1987.

R. Soeroso, Pengantar Ilmu Hukum (Sinar Grafika 2011) 77.

Satjipto Rahardjo, Ilmu Hukum (Citra Aditya Bakti, 1991) 92.

Ima Mayasari, 'Menggagas Omnibus Law' (Kumparan, 12 November 2018) <https://kumpa ran.com/dr-ima-mayasari-m-h/menggagas-omnibus-law-1542018891459839175> diakses 27 November 2018.

34 Barrack Obama, 'Obama Signs The Omnibus Public Lands Management Act of 2009' (New York Times, 30 Maret 2019) <https://www.nytimes.com/2009/03/30/us/politics/30lands-text.html> diakses 27 November 2018.
} 
pada perubahan kelembagaan yakni pada tataran mikro adalah kehendak individu untuk membangun koalisi di Congress, sedangkan pada tataran makro adalah kendala yang muncul di lingkungan Congress. Pada tataran mikro sangat penting untuk memperhatikan proses legislasi supaya sebuah rancangan UU menjadi UU. Terdapat dua hal yang harus dipastikan yakni koalisi di Congress untuk meloloskan UU dan veto dari Presiden harus dihindari. 35

Karakteristik utama omnibus law di Amerika Serikat adalah membantu anggota parlemen untuk membentuk konsensus. Hal ini disebabkan karena setiap anggota parlemen memiliki hak untuk melampirkan rancangan UUnya ke dalam omnibus law. Maka penerapan omnibus law lebih kepada gaya atau motif politik untuk melancarkan lolosnya sebuah RUU menjadi UU.

Penerapan omnibus law di Turki terdapat dalam UU No. 7161 (Law No. 7161) tentang Amandemen UndangUndang Pajak dan Undang-Undang lainnya. Sebagian besar UU ini mengatur tentang pajak, namun diatur pula mengenai perjanjian pengadaan publik, penerbitan sukuk yang dimiliki Kementerian Keuangan, dan langkah-langkah yang harus diambil untuk menstabilkan perekonomian. ${ }^{36}$

Omnibus law di Turki atau lebih populer disebut torba kanun cukup menarik karena dalam pembentukannya terdapat motif politik yakni pemerintah yang notabene di dominasi oleh partai tunggal mengendalikan pengaturan agenda legislatif. Pemerintah secara sah mengusulkan RUU yang paling mungkin disetujui oleh parlemen yang notabene didominasi oleh partai yang memerintah. Namun, secara ilegal pemerintah mencegah oposisi atau masyarakat yang meneliti RUU dengan cara menambahkan ketentuan baru dalam RUU setelah dibacakan dalam rapat pleno. ${ }^{37}$

Penerapan omnibus law di Turki oleh pemerintahan Adalet ve Kalkınma Partisi (Partai yang berkuasa saat ini) digunakan bersamaan dengan metode bantu untuk mempercepat proses legislasi. Terdapat dua metode bantu yakni "basic law mechanism" yang dijelaskan pada Pasal 91 The Rules of Procedure dan menyamarkan RUU dari pemerintah sebagai RUU dari anggota parlemen.

Pada metode yang pertama, ketentuan Pasal 91 mengatur bahwa jika terdapat perdebatan mengenai RUU yang diusulkan oleh pleno, maka RUU itu harus dibahas tetapi tidak per pasal melainkan per bagian. Masingmasing bagian terdiri tidak lebih dari 30 pasal. Pembahasan per bagian ini antara lain untuk efisiensi waktu karena tiga alasan. Pertama, setiap kelompok di parlemen, individu di parlemen, komite, dan pemerintah membahas RUU per bagian bukan per pasal. Kedua, sesi tanya jawab dialokasikan sekitar 15 menit untuk setiap bagian tidak seperti pembahasan tiap pasal yang mungkin menghabiskan waktu 10 menit setiap pasalnya. Dan ketiga, terdapat jumlah

\footnotetext{
35 Glen Stuart Krutz, 'Explaining Institutional Change: The Rise and Impact of Omnibus Legislating' (Disertasi PhD Texas A\&M University, Texas, 1999) 20.

36 Anonim, 'The Law Regarding The Amandments To Tax Laws, Certain Laws and Statutory Decrees Numberer 7161' (Deloite, 18 Januari 2019) <https://www.verginet.net/dtt/11/tax-news-20191.aspx> diakses pada 19 Februari 2019.

37 Yasushi Hasama dan Seref Iba, Loc.Cit.
} 
maksimal untuk mengamandemen atau mengubah rancangan undangundang yakni 2 pasal untuk basic law dan 7 pasal untuk ordinary law. Jika dibahas sebagai basic law, maka pemerintah bisa menghindari pembahasan untuk mengubah 7 pasal yang mungkin diajukan oleh oposisi. ${ }^{38}$

Awalnya metode ini digunakan untuk hukum dasar seperti hukum perdata, hukum pidana, dan hukum perdagangan, yang memiliki banyak pasal. Karena memang mustahil untuk mewujudkan reformasi hukum tanpa prosedur legislasi khusus karena waktu yang diperlukan untuk memberlakukan reformasi lebih lama dibandingkan dengan periode legislatif. Untuk itu digunakan metode ini untuk mencapai konsensus di antara semua partai politik. Pada waktu itu tidak ada keberatan dengan metode ini oleh karena itu masuk akal untuk menggunakan metode ini. Namun, setelah reformasi tercapai, metode ini mulai dipakai untuk semua UU tanpa mempertimbangkan isi dan jumlah pasalnya. Hal ini menjadi cara untuk menghapuskan prosedur legislatif.

Metode kedua yang jarang digunakan adalah menyamarkan RUU dari pemerintah sebagai RUU dari anggota parlemen. Konstitusi menetapkan bahwa RUU dari pemerintah sebelum dikirim ke parlemen harus terlebih dulu diberikan kepada LSM untuk mendapatkan saran dan analisis mereka terhadap dampak dari regulasi tersebut. Tetapi tidak ada syarat ini untuk RUU dari anggota parlemen. Untuk menghindari tahapan ini, anggota partai yang memerintah dapat mengirimkan RUU dari pemerintah seolah-olah rancangan tersebut dari anggota parlemen. Jika omnibus law dikombinasikan dengan metode ini dan basic law mechanism, maka akan memotong tahapan di pemerintah, komite dan pleno. Meskipun secara waktu efisien, tetapi cara ini rentan terhadap kesalahan legislatif. 39

Penggunaan ketiga cara yakni omnibus law, basic law mechanism dan menyamarkan RUU pernah dilakukan dalam menyusun Law No. 5335 yang mengubah beberapa UU dan Kanun Hükmünde Kararname (KHK). UU ini terdiri dari 36 pasal yang mengubah 163 pasal dari 53 hukum yang berbeda. Dengan demikian, masing-masing pasal Law No. 5335 mengubah lebih dari satu pasal dan satu UU dengan hanya ada sedikit koherensi antara UU dan pasal yang terdapat di dalamnya.

Mencermati contoh dan penjelasan sebelumnya, dapat disimpulkan bahwa karakteristik utama omnibus law di Turki adalah motif atau gaya politik untuk mempercepat dan mempersingkat proses legislasi dengan menggunakan metode bantu lain. Perbedaan proses legislasi antara yang diajukan oleh pemerintah dengan yang diajukan oleh anggota parlemen seperti di Turki tidak terdapat di Indonesia. Pemerintah dan DPR memiliki hak yang sama untuk mengusulkan RUU, namun tidak ada perbedaan prosedur jika diajukan oleh DPR atau sebaliknya akan lebih singkat. Adanya perbedaan itulah yang menurut pendapat Penulis menyebabkan adanya motif atau gaya politik yang terjadi di Turki. Namun cara demikian tidak bisa dikatakan ilegal karena diatur dalam konstitusi 
maupun peraturan perundangundangan.

\section{Karakteristik Omnibus Law}

Berdasarkan penelitian yang telah dilakukan sejauh ini, belum terdapat literatur ataupun ahli yang memberikan ciri atau karakteristik dari omnibus law. Hal ini dapat dimaklumi karena memang negaranegara yang secara jelas dan tegas mengatakan menerapkan omnibus law belum begitu banyak. Namun melihat praktik di beberapa negara, dapat disimpulkan beberapa hal yang menjadi karakteristik omnibus law. Mungkin karakteristik yang terdapat di dalam pandangan Penulis ini seringkali dilakukan dalam praktik legislasi di kebanyakan negara, namun tidak disadari atau tidak diakui sebagai omnibus law.

Penulis membedakan karakteristik ini menjadi dua yakni karakteristik umum dan karakteristik khusus. Karakteristik umum adalah karakteristik omnibus law yang semuanya harus dimiliki dalam setiap penerapan omnibus law. Sedangkan karakteristik khusus adalah karakteristik yang merupakan penunjang atau pelengkap karakteristik umum dan tidak harus semua karakteristik khusus tersebut diterapkan. Karakteristik umum omnibus law dibagi menjadi dua yakni:

1. Akselerasi Proses Legislasi

Dalam penerapan omnibus law harus terdapat karakteristik akselerasi proses legislasi. Hal ini disebabkan karena pada prinsipnya omnibus law dipilih untuk mewujudkan efisiensi dan efektivitas dalam proses legislasi. Tidak jarang proses legislasi dari awal hingga diundangkan memakan waktu berbulan-bulan bahkan bertahun-tahun. Dengan omnibus law yang dapat mempersingkat beberapa alur legislasi sehingga sebuah UU akan lebih cepat selesai.

2. Kompleksitas Permasalahan

Kompleksitas permasalahan yang dimaksud adalah banyaknya atau beragamnya permasalahan yang diatur dalam satu UU. Jika dalam suatu UU hanya mengatur satu jenis permasalahan saja, meskipun terdapat akselerasi proses legislasi di dalamnya maka tidak bisa disebut sebagai omnibus law, begitu juga sebaliknya. Secara sederhana, jika kita melihat pengertian omnibus law atau omnibus bill dalam Black's Law Dictionary, maka akan disebutkan "A single bill containing various distinct matters..." Selain itu, jika merujuk pada pendapat Prof. Jimly Asshiddiqie yang mengatakan terdapat tiga keadaan untuk mempraktekkan omnibus law, yakni UU yang akan diubah berkaitan secara langsung, UU yang akan diubah tidak berkaitan secara langsung, dan UU yang akan diubah tidak berkaitan tetapi dalam praktek bersinggungan, maka dapat ditarik kesimpulan pula bahwa masalah yang diatur pasti kompleks karena terdiri dari beberapa jenis permasalahan.

Selanjutnya, karakteristik khusus omnibus law juga dibagi menjadi dua yakni:

1. Berbentuk Kodifikasi

Kodifikasi adalah suatu bentuk hukum yang yang dibuat secara tertulis, dimana pembuatnya (legislative) memberikan suatu bentuk 
yurisdiksi khusus yang berisikan rumusan asas-asas yang dibuat secara tertulis sebagai suatu standar operasi berlakunya ketentuan dalam kodifikasi (exclusive operation/ exclusiver verwerking). .0 Kodifikasi memiliki tujuan mencapai kepastian hukum, penyederhanaan hukum dan kesatuan hukum. Hal ini sejalan dengan prinsip omnibus law yang mengedepankan efisiensi dan efektivitas. Contoh konkritnya adalah omnibus investment code of $1987 \mathrm{di}$ Filipina. Kodifikasi ini setidaknya berisi tentang investasi, ketenagakerjaan, sumber daya manusia, sumber daya alam, insentif fiskal dan non-fiskal. Meskipun tidak semua omnibus law berbentuk kodifikasi, tetapi penulis berpendapat dipilihnya bentuk kodifikasi akan membuat UU tersebut menjadi lebih sederhana dan mudah dipahami.

2. Gaya atau Motif Politik

UU adalah produk hukum yang pembuatannya tidak lepas dari proses politik. Gaya atau motif politik yang dimaksud disini merujuk kepada cara-cara yang digunakan legislatif maupun eksekutif untuk melancarkan proses legislasi. Gaya atau motif politik ini sebenarnya bertujuan untuk mengakselerasi proses legislasi, namun tidak jarang ditemukan dalam praktik bahwa gaya atau motif politik bertujuan untuk membentuk konsensus baik di partai politik, parlemen, maupun pemerintah dengan parlemen. Ataupun hal ini digunakan untuk memasukkan agenda politik tertentu.

\section{Proyeksi dan Tantangan Penerapan Omnibus Law di Indonesia}

Pemerintah telah berusaha untuk menciptakan iklim investasi yang baik di Indonesia lewat berbagai instrumen pengaturan baik itu PP, Perpres maupun Perda. Tersebarnya berbagai pengaturan tersebut menjadikannya tidak sederhana dan tidak adanya kesatuan hukum. Selain itu, tidak menutup kemungkinan akan timbul ketidakharmonisan hukum baik secara vertikal maupun horizontal. Hal ini perlu menjadi kesadaran pemerintah maupun pembentuk UU agar menciptakan suatu UU penanaman modal yang lengkap, sederhana, efisien dan efektif dalam menciptakan iklim investasi yang baik di Indonesia.

Pentingnya menciptakan iklim investasi yang kondusif dan memberikan fasilitas yang menunjang akan meningkatkan investasi di Indonesia. Instrumen untuk menciptakan iklim yang kondusif tersebut adalah hukum. Diperlukan hukum (dalam hal ini UU/peraturan) yang dapat mengakomodir keinginan para investor namun tidak mengabaikan kepentingan nasional. Pemerintah telah berusaha dengan menerbitkan berbagai PP, Perpres maupun Permen untuk mengakselerasi pertumbuhan investasi di Indonesia. Namun hal itu saja tidak cukup, perlu adanya suatu pengaturan yang terintegrasi sehingga memberikan kepastian hukum dan menghindari adanya disharmoni peraturan di kemudian hari.

40 Tim Pengajar Hukum Pidana UI, Position Paper (RKUHP Kodifikasi atau Kompilasi) (Bidang Studi Hukum Pidana UI, 2014) 4. 
Penulis berpendapat, Indonesia dapat mengadopsi omnibus law untuk menciptakan instrumen hukum investasi yang dapat meningkatkan minat investasi di Indonesia. Hal ini dikarenakan masalah yang diatur dalam hukum investasi sangatlah kompleks. Tidak hanya persoalan investor datang dan menanamkan modalnya, namun terkait erat dengan berbagai aspek seperti ketenagakerjaan, infrastruktur, insentif fiskal maupun non-fiskal dan lain sebagainya. Kompleksitas permasalahan ini lah yang belum diatur UU Penanaman Modal. Belakangan baru terpikirkan dan diterbitkan pengaturannya dalam bentuk PP, Perpres atau Permen.

Selain itu, Penulis berpandangan ini adalah hal yang mendesak sehingga memerlukan proses yang cepat namun tepat. Omnibus law dapat menjadi jawaban karena prosesnya yang memang mengedepankan efisiensi waktu pembahasan UU. Terlebih di Indonesia para anggota DPR seringkali disibukkan dengan kampanye politik di daerah-daerah. Hal ini tentu makin mempersempit ruang waktu untuk bekerja maksimal membahas UU.

Menurut Penulis, karakterisitik gaya atau motif politik dalam penerapan omnibus law yang digunakan di Amerika Serikat maupun Turki dapat diterapkan. Apalagi jika pemerintahan yang terbentuk pasca pemilu 2019 terfragmentasi seperti 2014 yang lalu, dimana pemerintahan dipegang oleh Presiden Joko Widodo dengan koalisinya yang disebut Koalisi Indonesia Hebat, sedangkan di parlemen dikuasai oleh Koalisi Merah Putih yang notabene berseberangan dengan pemerintah. Meskipun hal ini lambat laun mencair.
Mengapa hal ini menjadi sebuah keuntungan, karena masing-masing pihak memiliki posisi yang kuat dalam hal pembahasan sebuah UU. Jika ingin RUU-nya disetujui bersama dalam pembahasan, maka perlu dibentuk sebuah konsensus antara pemerintah dengan DPR. Jika merasa kepentingannya tidak di akomodir, maka dengan sangat mudah pihak yang merasa tidak diuntungkan akan tidak menyetujui RUU dalam pembahasan.

Dalam keadaan yang terfragmentasi pun, Penulis melihat ini adalah sebuah peluang besar untuk bisa melahirkan UU investasi yang baik dan dapat menciptakan iklim investasi yang kondusif, terlebih jika antara pemerintah dan parlemen tidak terfragmentasi. Hal ini akan jauh lebih mudah untuk diwujudkan.

Tantangan penerapan omnibus law yang sesungguhnya adalah memberikan pemahaman kepada semua pihak baik pemerintah maupun anggota DPR serta masyarakat luas tentang apa itu omnibus law. Penulis berpendapat, omnibus law bukanlah sesuatu hal yang baru dan asing di Indonesia. Ini adalah sebuah teknik untuk menyusun sebuah UU yang lebih efisien dan efektif. Justru teknik ini dapat membentuk konsensus antara pemerintah dan parlemen ketika terjadi deadlock. Diperlukan pula komitmen politik yang kuat di dalam parlemen karena parlemen menjadi kunci utama untuk mewujudkan omnibus law. Selama masih ada ego sektoral maka akan sulit untuk mewujudkan omnibus law.

Keberadaan omnibus law tidak akan mengganggu hierarki peraturan perundang-undangan sebagaimana diatur dalam Pasal 7 UU No. 12 Tahun 2011. Sejatinya omnibus law adalah 
teknik dan yang dilahirkan dari teknik tersebut adalah UU yang notabene produk hukum yang selama ini sudah ada. Bukan seperti pendapat beberapa pakar hukum yang mengatakan omnibus law sebagai UU payung karena hal tersebut tidak dikenal dalam hierarki peraturan perundangundangan di Indonesia.

Dalam omnibus law hendaknya berisi ketentuan-ketentuan dasar yang dapat dijadikan acuan bagi kementerian atau lembaga lain. Hal ini menjadi penting karena berangkat dari ketentuan dasar inilah sering timbul persoalan. Contoh dalam bidang kesehatan terdapat beberapa UU, antara lain UU Rumah Sakit, UU Praktik Kedokteran, UU Tenaga Kesehatan, UU Kebidanan, dan UU Farmasi. Beberapa pasal dalam UU Tenaga Kesehatan pernah diuji ke Mahkamah Konstitusi karena dinilai mengandung kekeliruan konspetual yang mencampuradukkan antara tenaga medis dan tenaga kesehatan lain tanpa membedakan mana tenaga profesi dan mana tenaga vokasi. Mahkamah Konstitusi membatalkan 4 dari 22 Pasal yang diujikan terkait istilah tenaga medis dan keberadaan Konsil Kedokteran Indonesia (KKI). ${ }^{41}$

Jika melihat UU No. 30 Tahun 2014 tentang Administrasi Pemerintahan (UU Administrasi Pemerintahan) sudah dimasukkan berbagai ketentuan dasar yang menjadi acuan dalam penyelenggaraan pemerintahan. UU Administrasi Pemerintahan memang tidak disusun menjadi sebuah omnibus law, namun materi muatannya bisa menjadi rujukan praktik omnibus law di Indonesia. Hal ini dapat menghindari terjadinya perbedaan definisi maupun kekeliruan konseptual antar satu UU dengan UU lainnya yang mengatur hal yang sama.

\section{PENUTUP}

Penerapan omnibus law di beberapa negara yang dibandingkan yakni Filipina, Amerika Serikat dan Turki memiliki persamaan dan perbedaan. Kompleksitas masalah yang diatur merupakan persamaan yang ditemukan dari penerapan omnibus law di ketiga negara tersebut. Ketiga negara itu menjadikan omnibus law sebagai pilihan untuk mengakomodir kebutuhan tersebut karena jika menggunakan UU konvensional, maka akan membutuhkan waktu yang lama. Artinya pada ketiga negara ini terdapat efisiensi waktu dalam pembahasan dan pengesahan UU. Sedangkan masing-masing negara memiliki karakteristik atau ciri khusus yang hanya terdapat di negara tersebut. Di Filipina, omnibus law diakomodir dalam bentuk kodifikasi. Sedangkan di Amerika Serikat dan Turki berbentuk UU. Bentuk ini tidak ada kaitannya dengan sistem pemerintahan maupun sistem hukum yang dianut negara tersebut. Pemilihan bentuk omnibus law lebih kepada halhal praktis untuk mengakomodir kebutuhan perancang UU. Karakteristik khusus yang terdapat di Amerika Serikat dan Turki adalah terdapat gaya atau motif politik untuk membentuk sebuah konsensus antara pemerintah dengan parlemen maupun di dalam parlemen itu sendiri. Namun takjarang motif politik ini menjadi

41 Anonim, 'MK Cabut Istilah 'Tenaga Medis' dan 'KKI' dari UU Tenaga Kesehatan' (Hukum Online, 14 Desember 2016) <https://www.hukumonline.com/berita/baca/lt5851234771b7e/mk-cabutistilah-tenaga-medis-dan-kki-dari-uu-tenaga-kesehatan> diakses 9 Mei 2019. 
"alat" untuk melangkahi beberapa proses legislasi yang seharusnya ditempuh.

Penyusunan UU bidang investasi di Indonesia jika dikaji dari pembentukan omnibus law sangat mungkin diterapkan dengan gaya khas Indonesia. Omnibus law sejatinya adalah teknik dalam penyusunan UU yang bertujuan untuk mewujudkan efisiensi dan efektivitas. Materi muatannya adalah ketentuan-ketentuan dasar yang menjadi acuan bagi kementerian atau lembaga lain. Keberadaan motif politik dan kemauan parlemen untuk membentuk omnibus law sangat berperan besar. Jika masih ada ego sektoral maka akan sulit untuk mewujudkan omnibus law. Selain itu, tantangan lain penerapan omnibus law adalah memberikan pemahaman kepada semua pihak baik pemerintah maupun anggota DPR serta masyarakat luas tentang apa itu omnibus law.

Penulis menyarankan perlu adanya komitmen politik dari penyusun UU yakni DPR bersama dengan Presiden (pemerintah) untuk mendukung terwujudnya omnibus law. Meskipun UU merupakan produk hukum namun penyusunannya tidak lepas dari proses politik. Selain itu perlu adanya keberanian dari pemerintah untuk melakukan bargaining dengan DPR dalam penyusunan UU yang mengedepankan prinsip kesetaraan posisi dalam pembahasan UU.

Di lain sisi perlu dilakukan inventarisir masalah terkait investasi yang komprehensif dan mendalam. $\mathrm{Hal}$ ini dilakukan supaya dalam menyusun UU investasi ke depan, semua aspek yang terkait dengan investasi sudah di pahami. Sehingga di kemudian hari tidak muncul kebingungan atau bahkan kekosongan hukum karena belum adanya instrumen hukum yang mengatur permasalahan tertentu. Kemudian, perlu dilakukan sosialisasi kepada pemerintah, anggota DPR, praktisi dan akademisi hukum serta masyarakat luas mengenai omnibus law beserta tujuan dan manfaatnya supaya ketika omnibus law diterapkan sudah tidak asing lagi.

\section{DAFTAR BACAAN}

\section{Buku}

Garner Bryan A (ed), Black's Law Dictionary (West Publishing Co 2004).

Kelsen H, General Theory of Law and State (Russell \& Russell 1945).

Indrati Maria F, Ilmu Perundang Undangan 1 (Kanisius 2007).

-----------, Ilmu Perundang-Undangan I1 (Kanisius 2007).

Marzuki Peter M, Pengantar Penelitian Hukum (Kencana 2014).

-----------, Penelitian Hukum (Kencana 2005).

Rahardjo S, Ilmu Hukum (Citra Aditya Bakti, 1991).

Ranggawidjaja H. R, Pengantar Ilmu Perundang-Undangan Indonesia (Mandar Maju 1998).

Seidman A, Seidman Robert B, dan Abeyesekere N, Legislative Drafting for Democratic Social Change (Kluwer Law International Ltd. 2001).

Soekanto S dan Mamudji S, Penelitian Hukum Normatif Suatu Tinjauan Singkat (RajaGrafindo Persada 2010).

Soeroso R, Pengantar Ilmu Hukum (Sinar Grafika 2011).

Tim Pengajar Hukum Pidana UI, Position Paper (RKUHP Kodifikasi atau Kompilasi) (Bidang Studi Hukum Pidana UI, 2014). 


\section{Artikel Jurnal}

Hasama $\mathrm{Y}$ dan Iba S, 'Legislative Agenda Setting by A Delegative Democracy: Omnibus Bills in Turkish Parliamentary System' (2017) 18 (2) Turkish Studies.

Irianto S, 'Metode Penelitian Kualitatif dalam Metodologi Penelitian Ilmu Hukum' (2002) 32 (2) Jurnal Hukum dan Pembangunan.

Nainggolan Sescio J, dkk., 'Analisis Yuridis Penentuan Kedudukan Saksi Pelaku Sebagai Justice Colaborators dalam Tindak Pidana Narkotika di Pengadilan Negeri Pematang Siantar' (2017) 5 (3) USU Law Jurnal.

Sonata Depri L, 'Metode Penelitian Hukum Normatif dan Empiris: Karakteristik Khas Dari MetodeMetode Meneliti Hukum' (2014) 8 (1) Fiat Justitia.

Trijono R, 'Alternatif Model Analisis Peraturan Perundang-Undangan' (2012) 1 (3) Rechtsvinding.

\section{Website}

Anonim, 'MK Cabut Istilah 'Tenaga Medis' dan 'KKI' dari UU Tenaga Kesehatan' (Hukum Online, 14 Desember 2016) <https://www. hukumonline.com/berita/baca/lt $5851234771 \mathrm{~b} 7 \mathrm{e} / \mathrm{mk}$-cabut-istila h-tenaga-medis-dan-kki-dari-uutenaga-kesehatan> diakses 9 Mei 2019.

Anonim, 'Rantai Birokrasi Masih Jadi Kendala Investor Berinvestasi di Indonesia' (Okefinance, 12 Februari 2018) <https://econom y.okezone.com $/ \mathrm{read} / 2018 / 02 / 12$ /320/1858267/rantai-birokrasimasih-jadi-kendala-investor-berin vestasi-di-indonesia> diakses 27 November 2018.

Anonim, The Law Regarding The Amandments To Tax Laws, Certain Laws and Statutory Decrees Numberer 7161' (Deloite, 18 Januari 2019) <https://www.vergi net.net/dtt/11/tax-news-2019 1.aspx $>$ diakses pada 19 Februari 2019.

Bierscbach B, 'Everything You Need to Know About Omnibus Bills, and Why They're So Popular at The Minnesota Legislature' (Minnpost, 31 Maret 2017) <https://www. minnpost.com/politics-policy/20 $17 / 03$ /everything-you-need-know -about-omnibus-bills-and-why-the yre-so-pop ular-minne> diakses 17 Maret 2018.

Cabote Regulus E, 'Philippines: Investment Incentives Under The Omnibus Investment Code of The Philippines' (Mondaq, 17 Januari 2001) <http://www. mondaq.com/x/9714/Investmen $\mathrm{t}+$ Strategy/Investment+Incentives +Under+The+Omnibus+Investmen $\mathrm{t}+$ Code+Of+The+Philippines $>$ diakses 27 November 2018.

Ihsanuddin, 'Tinjau Kantor BKPM, Jokowi Sebut Urus Izin Investasi Hanya Butuh 2 Jam' (Kompas.com, 14 Januari 2019) <https://nasional.kompas.com/re ad/2019/01/14/12570161/tinja u-kantor-bkpm-jokowi-sebut-uru s-izin-investasi-hanya-butuh-2jam> diakses 1 April 2019.

Ikhsan M, 'Wabup Dalmasri: Perizinan Online Hindari Pelaku UKM di Bintan dari Calo' (Batamnew s.co.id, 27 Maret 2019) <https:// www.batamnews.co.id/berita-462 08-wabup-dalmasri-perizinan-onl ine-hindari-pelaku-ukm-di-bintan -dari-calo.html> diakses 1 April 2019.

Mayasari I, 'Menggagas Omnibus Law' (Kumparan, 12 November 2018) <https://kumparan.com/dr-imamayasari-m-h/menggagas-omnib us-law-1542018891459839175> diakses 27 November 2018.

Nadia A, 'Urus Izin Investasi Hanya 1 Jam dengan Online Single Submission' (Kompas.com, 25 Mei 2018) < https://ekonomi.kompas. 
$\mathrm{com} / \mathrm{read} / 2018 / 05 / 25 / 1249315$

26/urus-izin-investasi-hanya-1-ja m-dengan-online-single-submissi on> diakses 1 April 2019.

Obama B, 'Obama Signs The Omnibus Public Lands Management Act of 2009' (New York Times, 30 Maret 2009) <https://www.nytimes.co $\mathrm{m} / 2009 / 03 / 30 /$ us/politics/30la nds-text.html> diakses $\quad 27$ November 2018.

Permana E, 'Banyak UU Hambat Usaha, Pemerintah Akan Buat Omnibus Law' (Breaking, 28 Maret 2018) <https://www.aa. com.tr/id/ekonomi/banyak-uu-h ambat-usaha-pemerintah-akanbuat-omnibus-law/1101481> diakses 27 November 2018.

Rahayu Yayu A, "Regulasi Masih Menjadi Kendala Investasi di Indonesia' (Merdeka.com, 25 September 2018) <https://www. merdeka.com/uang/regulasi-masi h-jadi-kendala-investasi-di-indon esia.html> diakses 27 November 2018.

Wandi, 'DPR Puji Sistem Perizinan Investasi OSS Dunia Usaha' (InfoPublik, 19 Februari 2019) <http://infopublik.id/kategori/po litik-hukum/328424/dpr-puji-sis tem-perizinan-investasi-oss-duni a-usaha?video=> diakses 1 April 2019.

\section{Thesis/Disertasi}

Krutz Glen S, 'Explaining Institutional Change: The Rise and Impact of Omnibus Legislating' (Disertasi PhD Texas A\&M University, Texas, 1999).

\section{Peraturan Perundang-Undangan}

Undang-Undang Nomor 12 Tahun 2011 tentang Pembentukan Peraturan Perundang-Undangan. 
